\title{
Response of soil microorganisms to radioactive oil waste: results from a leaching experiment
}

\author{
P. Galitskaya ${ }^{1}$, L. Biktasheva ${ }^{2}$, A. Saveliev ${ }^{3}$, S. Ratering ${ }^{4}$, S. Schnell ${ }^{4}$, and S. Selivanovskaya ${ }^{2}$ \\ ${ }^{1}$ Department of Landscape Ecology, Kazan State University, Kazan, Russian Federation \\ ${ }^{2}$ Department of Applied Ecology, Kazan State University, Kazan, Russian Federation \\ ${ }^{3}$ Department of Ecological Systems Modeling, Kazan State University, Kazan, Russian Federation \\ ${ }^{4}$ Institute of Applied Microbiology, Justus Liebig University, Giessen, Germany \\ Correspondence to: P. Galitskaya (gpolina33@yandex.ru)
}

Received: 6 October 2014 - Published in Biogeosciences Discuss.: 29 January 2015

Revised: 8 May 2015 - Accepted: 8 May 2015 - Published: 16 June 2015

\begin{abstract}
Oil wastes produced in large amounts in the processes of oil extraction, refining, and transportation are of great environmental concern because of their mutagenicity, toxicity, high fire hazardousness, and hydrophobicity. About $40 \%$ of these wastes contain radionuclides; however, the effects of oil products and radionuclides on soil microorganisms are frequently studied separately.

The effects on various microbial parameters of raw waste containing $575 \mathrm{~g}$ of total petroleum hydrocarbons (TPH) $\mathrm{kg}^{-1}$ waste, 4.4 of ${ }^{226} \mathrm{Ra}, 2.8$ of ${ }^{232} \mathrm{Th}$, and $1.3 \mathrm{kBq} \mathrm{kg}^{-1}$ of ${ }^{40} \mathrm{~K}$ and its treated variant $\left(1.6 \mathrm{~g} \mathrm{~kg}^{-1}\right.$ of TPH, 7.9 of ${ }^{226} \mathrm{Ra}$, 3.9 of ${ }^{232} \mathrm{Th}$, and $183 \mathrm{kBq} \mathrm{kg}^{-1}$ of ${ }^{40} \mathrm{~K}$ ) were examined in a leaching column experiment to separate the effects of hydrocarbons from those of radioactive elements. The raw waste sample $(H)$ was collected from tanks during cleaning and maintenance, and a treated waste sample $(R)$ was obtained from equipment for oil waste treatment. Thermal steam treatment is used in the production yard to reduce the oil content.

The disposal of $H$ waste samples on the soil surface led to an increase in the TPH content in soil: it became 3.5, 2.8, and 2.2 times higher in the upper $(0-20 \mathrm{~cm})$, middle $(20-40 \mathrm{~cm})$, and lower $(40-60 \mathrm{~cm})$ layers, respectively.

Activity concentrations of ${ }^{226} \mathrm{Ra}$ and ${ }^{232} \mathrm{Th}$ increased in soil sampled from both $H$ - and $R$ - columns in comparison to their concentrations in control soil. The activity concentrations of these two elements in samples taken from the upper and middle layers were much higher for the $R$-column compared to the $H$-column, despite the fact that the amount of waste added to the columns was equalized with respect to the activity concentrations of radionuclides.
\end{abstract}

The $H$ waste containing both TPH and radionuclides affected the functioning of the soil microbial community, and the effect was more pronounced in the upper layer of the column. Metabolic quotient and cellulase activity were the most sensitive microbial parameters as their levels were changed 5-1.4 times in comparison to control ones. Changes in soil functional characteristics caused by the treated waste containing mainly radionuclides were not observed. PCRSSCP (polymerase chain reaction - single strand conformation polymorphism) analysis followed by MDS (metric multidimensional scaling) and clustering analysis revealed that the shifts in microbial community structure were affected by both hydrocarbons and radioactivity. Thus, molecular methods permitted to reveal the effects on soil microbial community not only from hydrocarbons, which significantly altered functional characteristics of soil microbiome, but also from radioactive elements.

\section{Introduction}

Oil wastes generated during processing, transportation, and refining of petroleum are serious environmental threats, especially in petroleum-producing regions (Liu et al., 2009; Wang et al., 2012). These wastes contain oily components, water, and mineral fractions, which can include naturally occurring radioactive elements such as thorium, potassium, radium, and others (Abo-Elmagd et al., 2010; Bakr, 2010). Yearly, about 60 million tons of oily wastes are generated (Hu et al., 2013). About $30-40 \%$ of the oil wastes are ra- 
dioactive; thus, this type of waste is very common (Al-Masri et al., 2004; Hamlat et al., 2001; Selivanovskaya et al., 2013). The waste materials are hazardous to plants, animals, and microorganisms due to the presence of toxic and mutagenic compounds and their interactions (Marin et al., 2005; Verma et al., 2006). In Russia, these wastes are usually disposed of on the soil surface along the roads, around the new industrial buildings and buildings under construction, etc. (Galitskaya et al., 2014; Selivanovskaya et al., 2012). When disposed of on the surface soil and exposed to precipitation, components of the oil wastes can leach into the soil, altering the chemical, physical, and biological properties (Mikkonen et al., 2012). As oil wastes are mixtures of inorganic and organic compounds which can degrade to metabolites of unknown persistence and toxicity, chemical quantification is insufficient to estimate the environmental risk (Morelli et al., 2005; Mikkonen et al., 2012).

Microorganisms are an essential part of terrestrial ecosystems, playing important roles in soil biogeochemical cycles (Marcin et al., 2013; Li et al., 2013). Soil microbial properties appear to be good indicators of soil pollution, as they are very responsive and provide information about the changes occurring in soil (Marin et al., 2005; Tejada et al., 2008). Soil microbial biomass and basic respiration are the two parameters that are traditionally used to estimate soil quality, particularly for soils polluted by hydrocarbons (Labud et al., 2007; Lee et al., 2008; Lamy et al., 2013). Another microbial parameter which can sensitively reflect the quality of soils is microbial enzymes, as they participate in the biological cycling of elements and the transformation of organic and mineral compounds (Marin et al., 2005).

Changes in abiotic and biotic ecological factors significantly affect the structure of bacterial and fungal soil communities; therefore, these changes can be used as a tool for soil impact assessment (Huang et al., 2013). To investigate the microbial community, shifts in soils, culture-independent molecular techniques such as clone libraries, gradient gel electrophoresis, single strand polymorphisms, terminal restriction fragment length polymorphism, deep sequencing, and quantitative real-time polymerase chain reaction are used (Adetutu et al., 2013; Bacosa et al., 2012; Liu et al., 2013).

The effects of crude oil and oil waste on soil and its microbial community have been studied (Lee et al., 2008; Labud, 2007; Marin et al., 2005; Admon et al., 2001), while fewer publications are devoted to the hazards of naturally occurring radioactive elements (Abo-Elmagd et al., 2010; Hrichi et al., 2013) or their effects on bacteria (Zakeri et al., 2012). Hydrocarbons can cause direct toxic effects on microbial cells due to their ability to change fluidity and permeability of cell membranes and to alter cell homeostasis, to inhibit enzymes, to disrupt the electron transport chain and oxidative phosphorylation, and to cause lipid proliferation (Ruffing and Trahan, 2014). Besides, hydrocarbon may cause indirect effects on soil bacteria by changing aeration and water regimes. Radionuclides may cause chromosomal aberrations, single strand breaks and base pair substitution in the DNA of microorganisms (Min et al., 2003). The combined effects of wastes, consisting of both heavy fraction hydrocarbons and radionuclides, on soil still need to be investigated.

We hypothesized that the oil wastes disposed of on soil surfaces affect the microbial communities due to both hydrocarbons and radioactive elements contained in them. To assess these effects, column experiments were performed. Raw (containing oily compounds and radionuclides) and treated waste (containing mainly radionuclides) samples from a petroleum production yard were investigated. The effects of total petroleum hydrocarbons (TPH) and radioactive elements on three soil layers in columns (0-20, 20-40, and $40-60 \mathrm{~cm}$ ) were investigated to characterize: (a) the rate of migration of these contaminants, (b) the effects on the microbiological characteristics of the soil layers (metabolic coefficient and enzyme activities), and (c) shifts in the structure of bacterial communities by means of polymerase chain reaction - single strand conformation polymorphism (PCRSSCP).

\section{Materials and methods}

\subsection{Experimental design}

In the experiment we used six soil columns of $60 \mathrm{~cm} \times 10 \mathrm{~cm}$ $\times 10 \mathrm{~cm}$ (height $\times$ length $\times$ width) with undestroyed native soil (Luvisol, $\mathrm{C}_{\text {org }}=1.2 \%, \mathrm{~N}_{\text {tot }}=0.11 \%, \mathrm{~K}_{\mathrm{ext}}=91 \mathrm{~g} \mathrm{~kg}^{-1}$, $\mathrm{P}_{\text {ext }}=125 \mathrm{~g} \mathrm{~kg}^{-1}$ ) collected from the Matyushenski forest nursery, Tatarstan, Russia (latitude: $55^{\circ} 48^{\prime} 07^{\prime \prime} \mathrm{N}$, longitude: $\left.49^{\circ} 16^{\prime} 13^{\prime \prime} \mathrm{E}\right)$. Two columns were not artificially contaminated by waste samples and served as a control ( $C$-columns). On the top of the other four columns we disposed of two waste samples (each waste sample in two replicates), and thus the soil of these columns was considered to be contaminated.

Sixteen waste samples were collected from tanks, pipes, and production equipment in different seasons between 2010 and 2012 at the Tikchonovskii petroleum production yard (Tatarstan, Russia; latitude: $54^{\circ} 50^{\prime} 26^{\prime \prime} \mathrm{N}$, longitude: $\left.52^{\circ} 27^{\prime} 08^{\prime \prime} \mathrm{E}\right)$. Two of these waste samples were used for analysing the toxicity and in the soil column experiment: a raw waste sample $(H)$ collected from tanks during cleaning and maintenance, and a treated waste sample $(R)$ obtained from equipment for oil waste treatment. The TPH of the $H$ sample contained $36 \%$ aromatics, $27 \%$ alphaltenes, $16 \%$ aliphatics, and $21 \%$ resins. Thermal steam treatment is used in the production yard to reduce the oil content. The quantity of waste samples $H$ and $R$ loaded onto soil columns was calculated to equalize the activity concentrations of ${ }^{226} \mathrm{Ra}$ (about $1 \mathrm{kBq} \mathrm{kg}^{-1} ; H$-columns and $R$-columns, correspondingly). Over 30 days, the waste samples were situated on the top of the soil columns and the rainfall was simulated based 
upon the average atmospheric precipitation for the European part of Russia (650 $\mathrm{mm}$ a year).

After a month at $25^{\circ} \mathrm{C}$, soil from each column was divided into three parts (upper layer: $0-20 \mathrm{~cm}(u)$, middle layer: 20 $40 \mathrm{~cm}(\mathrm{~m})$, and lower layer: $40-60 \mathrm{~cm}(l)$ to give soil samples $\mathrm{Hu}, \mathrm{Hm}, \mathrm{Hl}, \mathrm{Ru}, \mathrm{Rm}, \mathrm{Rl}$, and $\mathrm{Cu}, \mathrm{Cm}, \mathrm{Cl}$ ) and analysed.

\subsection{Chemical parameters}

The total petroleum hydrocarbon (TPH) content in waste and soil samples was determined by IR-spectrometry with an AN-2 analyser (LLC NEFTEHIMAVTOMATIKA-SPb, Saint Petersburg, Russia). Fractionation of TPH into aromatics, aliphatics, asphaltenes, and resins was done by silica gel column chromatography followed by gravimetric analysis (Walker et al., 1975). TPH extracts were dissolved in $n$-pentane and separated into soluble and insoluble fractions (asphaltene). The soluble fraction was loaded on the top of a silica gel $\mathrm{G}(60-120 \mathrm{mesh})$ column $(2 \mathrm{~cm} \times 30 \mathrm{~cm})$ and eluted with solvents of different polarities. The alkane fraction was eluted with $100 \mathrm{~mL}$ of hexane and then the aromatic fraction was eluted with $100 \mathrm{~mL}$ of toluene. The resin fraction was eluted with $100 \mathrm{~mL}$ of methanol and chloroform (Mishra, 2001).

Samples were dried for $24 \mathrm{~h}$ at $110^{\circ} \mathrm{C}$, homogenized, and sieved through a $0.8 \mathrm{~mm}$ mesh. The sieved samples were weighed, packed in a Marinelli-type beaker $(1000 \mathrm{~mL})$, sealed, and stored for 4 weeks to reach equilibrium between ${ }^{226} \mathrm{Ra}$ and its decay product. Gamma-ray spectrometric measurements for natural radioactivity $\left({ }^{226} \mathrm{Ra},{ }^{232} \mathrm{Th}\right.$, and ${ }^{40} \mathrm{~K}$ ) were performed with a Progress gamma spectrometer (SPC Doza, Zelenograd Moscow, Russia) using a scintillation block for detection based on a crystal of sodium iodide (Fotiou et al.,1998) at a resolution of $30 \mathrm{keV}$ at the $662 \mathrm{keV}$ Cs-137 gamma line.

The total organic carbon content in waste samples was estimated according to ISO 10694:1995, the total nitrogen content according to ISO 11261:1995, $\mathrm{pH}$ according to ISO 10390:2005, and electroconductivity according to ISO 11265:1994.

\subsection{Microbiological analysis}

Soil metabolic quotient $\left(q \mathrm{CO}_{2}\right)$ was calculated as the ratio of basal microbial respiration to soil microbial biomass (Anderson and Domsch, 1990). Basal respiration rates were determined according to Schinner et al. (1995), and microbial biomass according to ISO 14240-2 (1997).

The dehydrogenase (DHA) activity of microorganisms was determined according to the method described in Garcia et al., (1997). Soil $(1 \mathrm{~g})$ adjusted to $60 \%$ water-holding capacity was treated with $0.2 \mathrm{~mL}$ of $4 \% 2$ - $p$-iodophenyl-3- $p$ nutrophenyl-5-phenyltetrazolium chloride and incubated at $22^{\circ} \mathrm{C}$ in darkness (autoclaved soil samples were used as controls). After $20 \mathrm{~h}$, the iodonitrotetrazolium formazan (INTF) was extracted with $10 \mathrm{~mL}$ of ethylene chloride / acetone (2: 3 ), measured spectrophotometrically at $490 \mathrm{~nm}$, and the results were expressed as mg INTF $\mathrm{g}^{-1}$ dry soil $\mathrm{h}^{-1}$.

Cellulase activity (CA) was estimated by hydrolysis of carboxymethylcellulose according to the method described in Pancholy and Rice, (1973) with modifications: soil (3 g) adjusted to $60 \%$ water holding capacity, $7.5 \mathrm{~mL}$ of $1.15 \mathrm{M}$ phosphate buffer, $5 \mathrm{~mL}$ of $1 \%$ carboxymethylcellulose, and $0.5 \mathrm{~mL}$ of toluene were incubated at $28^{\circ} \mathrm{C}$ for $24 \mathrm{~h}$. The samples were filtered and $2 \mathrm{~mL}$ of dinitrosalicylic acid reagent $(10 \mathrm{~g}$ of 3.5-dinitrosalicylic acid, $16 \mathrm{~g}$ of $\mathrm{NaOH}$, and $300 \mathrm{~g}$ of K-Na-tartrate tetrahydrate in $1 \mathrm{~L}$ of distilled water) was added to $4 \mathrm{~mL}$ of filtrate. The samples were then incubated at $95^{\circ} \mathrm{N}$ for $10 \mathrm{~min}$ in a water bath, cooled, and measured at $540 \mathrm{~nm}$. Results were expressed as milligrams of reducing sugars in $1 \mathrm{~g}$ of dry soil.

\subsection{Single strand conformation polymorphism}

Soil samples were sieved (4 mm mesh) and homogenized, DNA was extracted using the FastDNA ${ }^{\circledR}$ SPIN Kit for Soil (Bio101, Qbiogene, Heidelberg, Germany) according to the instructions provided, and the DNA concentration was measured at $260 \mathrm{~nm}$ (Thermo Scientific GENESYS $20^{\mathrm{TM}}$, Thermo Fisher Scientific Inc., Waltham, USA). DNA extracts were stored at $-20^{\circ} \mathrm{C}$ for further analysis. Extraction was performed twice for contaminated and control samples.

SSCP fingerprinting of the bacterial communities was performed as described by Kampmann et al. (2012). Briefly, a PCR was performed (MyCycler, Bio-Rad, Munich, Germany) in a total volume of $50 \mu \mathrm{L}$ using chemicals and enzymes purchased from Fermentas (St. Leon-Rot, Germany). The reaction mixture contained 0.6 of $0.02 \mu \mathrm{L}^{-1}$ Dream Taq DNA Polymerase, $5 \mu \mathrm{L}$ of $1 \times$ Taq Buffer, $4 \mu \mathrm{L}$ of $2 \mathrm{mM} \mathrm{MgCl}_{2}, 5 \mu \mathrm{L}$ of $0.2 \mathrm{mM}$ of each dNTP, $1 \mu \mathrm{L}$ of $0.2 \mu \mathrm{mol}^{-1}$ of each primer, $1 \mu \mathrm{L}$ of $0.16 \mathrm{mg} \mathrm{mL}^{-1} \mathrm{BSA}$, and $2 \mu \mathrm{L}$ of DNA. Bacterial communities were analysed using the universal bacterial 16S rRNA gene primer pair Com1/Com2 (CAG CAG CCG CGG TAA TAC / CCG TCA ATT CCT TTG AGT TT) (Schwieger and Tebbe, 1998) purchased from Eurofins MWG Operon (Ebersberg, Germany). The PCR parameters were $95^{\circ} \mathrm{C}$ for $3 \mathrm{~min}$, followed by 16 cycles at $94^{\circ} \mathrm{C}$ for $30 \mathrm{~s}, 64-57^{\circ} \mathrm{C}$ for $30 \mathrm{~s}$, and $72^{\circ} \mathrm{C}$ for $30 \mathrm{~s}$, followed by 9 cycles at $94^{\circ} \mathrm{C}$ for $30 \mathrm{~s}, 57^{\circ} \mathrm{C}$ for $30 \mathrm{~s}$, and $72^{\circ} \mathrm{C}$ for $30 \mathrm{~s}$, with a final elongation step of $30 \mathrm{~min}$ at $72^{\circ} \mathrm{C}$. PCR products were purified using the QiaQuick PCR Purification Kit (Qiagen, Hilden, Germany). Before electrophoresis, ssDNA fragments were generated by lambda exonuclease digestion according to Schwieger and Tebbe (1998). The ssDNA was separated using the INGENYphorU electrophoresis system (Ingeny International BV, Goes, Netherlands) at $450 \mathrm{~V}$ and $19.5^{\circ} \mathrm{C}$ for $17 \mathrm{~h}$ in a non-denaturing polyacrylamide gel consisting of $0.6 \times \mathrm{MDE}$ solution (Biozym Scientific GmbH, Hessisch Oldendorf, Germany) and $1 \times$ TBE buffer (0.89 M Tris, $0.89 \mathrm{M}$ boric acid, and $20 \mathrm{mM}$ EDTA pH 
8.0). The gel was silver-stained using the Page Silver Staining Kit (Fermentas, St. Leon-Rot, Germany) according to the instructions provided and scanned to obtain digitized gel images.

\subsection{Identification of excised bands}

Dominant bands were excised from SSCP gels as described by Schwieger and Tebbe (1998). The gel-extracted DNA was reamplified and cloned as described by Kampmann et al. (2012) using the pGEM-T ${ }^{\circledR}$ Vector System (Promega, Mannheim, Germany). The four clones of each band to be sequenced (LGC Genomics GmbH, Berlin, Germany) using the M13 (Promega, Mannheim, Germany) forward primer were sent to LGC Genomics GmbH (Berlin, Germany) in a 96-well microtiter plate filled with LB (Lysogeny Broth)Agar with $50 \mu \mathrm{g} \mathrm{mL}^{-1}$ of ampicillin.

Quality checks and cutting of sequences were performed using the software package MEGA version 5.0 (Tamura et al., 2011). Sequences were analysed for chimeras with the Pintail programme (Version 1, Cardiff School of Biosciences, Cardiff, United Kingdom; Ashelford et al., 2005), and putative chimeras were removed from the data set. Alignments were done with the SILVA web aligner (SINA v1.2.11, Microbial Genomics and Bioinformatics Research Group, Bremen, Germany; Pruesse et al., 2007), and similarity values were calculated using the PHYLIP neighbour-joining algorithm (Felsenstein, 1989) implemented in the ARB software package (Ludwig et al., 2004). For sequence comparison, the SILVA SSU 106 Ref database was used. Sequences were deposited in the NCBI GenBank database with the accession numbers KF926419-KF926433.

\subsection{Statistical analysis}

Sampling and chemical analyses were carried out in triplicate and biological analyses in quintuplicate, and all results were expressed on an air-dried soil basis. Random variability of data was analysed to determine the mean values and standard errors (S.E.). Statistical analyses were performed using Origin 8.0 (OriginLab, Northampton, USA) and R Statistical Software (R 3.0.0, R Foundation for Statistical Computing Version, Vienna, Austria; R Development Core Team, 2012) packages.

SSCP gels were scanned at $400 \mathrm{dpi}$ and the number of SCCP bands and their areas and integrated intensities were estimated with Quantity One 1-D Analysis Software (Biorad, Hercules, CA, USA). Each band was used as the measured unit of biodiversity. Microbial community diversity was expressed using several indices: Shannon-Weaver ( $H$-index) and Simpson ( $D$-index) indices were calculated according to Shannon and Weaver, (1963) and Simpson, (1949), respectively; the species diversity ( $S$-index) corresponded to the number of species in the line; the simple index ( $I$-index) was calculated as the number of bands in the SSCP line divided by the number of bands in the line with the highest number of bands estimated according to Silvestri et al., (2007); and the equitability of the bands was calculated by Shannon's evenness ( $E$-index; Zornoza et al., 2009).

Two-way ANOVA with interaction was used to analyse the impact of factors (e.g. depth of soil layers or type of contaminant) on the presence of bands and microbial community diversity indices, and results yielding a $p$ value less than 0.01 were considered highly significant (Chambers and Hastie, 1992). In all ANOVA, the number of degrees of freedom was two for the type of contaminant, two for the depth of soil layers, four for the interaction of these two factors, and nine for the residuals. The $F$-statistic was in the range $[6,17.6]$ ( $p$ value range $[0.02,0.001])$ for the type of contaminant, $[0.7596,11.5]$ ( $p$ value range $[0.5,0.003]$ ) for the depth of soil layers, and $[1.9,5.1]$ ( $p$ value range $[0.2,0.02]$ ) for the interaction of these two factors. To visualize the differences in microbial communities, metric multidimensional scaling (MDS) plots were created, where matrices of band abundance were assembled, and similarity matrices were calculated according to the Bray-Curtis coefficient (Faith et al., 1987).

Cluster analysis was performed using hierarchic clusterization based on a matrix of microbial communities dissimilarity. The Ward minimum variance method from the Vegan package of the R software (R Foundation for Statistical Computing Version 3.0.0, Vienna, Austria; R Development Core Team, 2012), which aims to find compact, spherical clusters, was implemented for clusterization (Ward, 1963).

\section{Results and discussion}

\subsection{Chemical characterization of the wide range of waste samples}

Oil wastes can contain radioactive elements and hydrocarbons in various concentrations (Lazar et al., 1999). In our work, we estimated TPH content and activity concentrations of 16 oily wastes sampled at a petroleum production yard. As shown in Table 1, the TPH content ranged from 1.6 to $880.3 \mathrm{~g} \mathrm{~kg}^{-1}$, the activity concentration of ${ }^{226} \mathrm{Ra}$ ranged from 0.03 to 7.92 , that of ${ }^{232} \mathrm{Th}$ ranged from 0.02 to 5.09 , and that of ${ }^{40} \mathrm{~K}$ ranged from 0.03 to $2.28 \mathrm{kBq} \mathrm{kg}^{-1}$. The values obtained are comparable to or slightly exceed values reported by other authors (Liu et al., 2009; Ros et al., 2010; Gazineu and Hazin, 2008; El Afifi and Awwad, 2005; Ayotamuno et al., 2007).

The waste pairs 13/14 and 15/16 marked in Table 1 represent the two pairs of untreated and treated waste samples. The treatment of these wastes, which is a thermal steam treatment with chemical agents, is part of the industrial process. The goal of the treatment is to reduce the hazardous properties of the wastes. 
Table 1. Chemical properties of the oil wastes from the Tikchonovskii petroleum production yard.

\begin{tabular}{lrrrr}
\hline Waste sample & $\mathrm{TPH}$, & \multicolumn{3}{c}{ Activity concentration, $\mathrm{kBq} \mathrm{kg}^{-1}$} \\
number & $\mathrm{g} \mathrm{kg}^{-1}$ & ${ }^{226} \mathrm{Ra}$ & ${ }^{232} \mathrm{Th}$ & \\
\hline 1 & $35.0 \pm 7.0$ & $7.93 \pm 1.62$ & $2.40 \pm 1.88$ & not detected \\
2 & $59.0 \pm 11.8$ & $0.62 \pm 0.14$ & $0.35 \pm 0.07$ & not detected \\
3 & $90.4 \pm 18.1$ & $1.70 \pm 0.37$ & $0.30 \pm 0.06$ & $0.26 \pm 0.04$ \\
4 & $880.3 \pm 176.8$ & $0.07 \pm 0.02$ & $0.02 \pm 0.01$ & $0.03 \pm 0.01$ \\
5 & $95.4 \pm 19.1$ & $1.81 \pm 0.39$ & $0.28 \pm 0.06$ & $0.26 \pm 0.04$ \\
6 & $720.1 \pm 144.3$ & $2.74 \pm 0.60$ & $0.92 \pm 0.18$ & $0.27 \pm 0.04$ \\
7 & $123.3 \pm 24.6$ & $0.03 \pm 0.01$ & $0.03 \pm 0.01$ & $0.06 \pm 0.01$ \\
8 & $57.4 \pm 11.5$ & $0.28 \pm 0.06$ & $0.15 \pm 0.03$ & $0.05 \pm 0.01$ \\
9 & $59.2 \pm 11.8$ & $0.25 \pm 0.05$ & $0.11 \pm 0.02$ & $0.06 \pm 0.01$ \\
10 & $30.5 \pm 6.1$ & $0.43 \pm 0.10$ & $0.20 \pm 0.04$ & $0.14 \pm 0.02$ \\
11 & $46.5 \pm 9.3$ & $1.48 \pm 0.33$ & $0.12 \pm 0.03$ & $0.06 \pm 0.01$ \\
12 & $153.1 \pm 30.6$ & $0.47 \pm 0.10$ & $0.25 \pm 0.05$ & $0.06 \pm 0.01$ \\
$13 *$ (further $H$ ) & $575.2 \pm 121.0$ & $4.40 \pm 0.97$ & $2.85 \pm 0.57$ & $1.28 \pm 0.19$ \\
$14^{*}$ (further $R$ ) & $1.6 \pm 0.2$ & $7.92 \pm 0.93$ & $3.99 \pm 0.44$ & $1.79 \pm 0.21$ \\
$15^{* *}$ & $640.1 \pm 128.3$ & $3.86 \pm 0.20$ & $3.39 \pm 0.08$ & $1.27 \pm 0.04$ \\
$16^{* *}$ & $4.6 \pm 0.9$ & $7.86 \pm 1.73$ & $5.09 \pm 1.02$ & $2.28 \pm 0.34$ \\
\hline * Pair of wastes in which waste sample no. 13 is raw waste and waste sample no. 14 is the waste \\
obtained by steam treatment of waste sample no. 13.* Pair of wastes in which waste sample no. 15 is \\
raw waste and waste sample no. 16 is the waste obtained by steam treatment of waste sample no. 15.
\end{tabular}

For further investigation, we have chosen wastes 13 (further $H$ ) and 14 (further $R$ ) for the following reasons: (i) from the waste samples studied, the initial waste sample $H$ possesses quite a high concentration of TPH and, at the same time, high activity concentrations of radionuclides; (ii) from the waste samples studied, the treated waste sample $R$ possesses the highest activity concentration of ${ }^{226} \mathrm{Ra}$ and the second highest activity concentrations of ${ }^{232} \mathrm{Th}$ and ${ }^{40} \mathrm{~K}$; (iii) the composition of the mineral part of the $R$-sample is the same as that of the $H$-sample, so the effects of removing hydrocarbons from the waste can be studied.

\subsection{Chemical characterization of the waste samples $H$ and $\boldsymbol{R}$}

As shown in Table 1, the TPH content in sample $H$ was estimated to be $575.2 \pm 121.0 \mathrm{~g} \mathrm{~kg}^{-1}$, which is typical for this waste (Ayotamuno et al., 2007; Al-Futaisi et al., 2007; Tahhan and Abu-Ateih, 2009; Selivanovskaya et al., 2013). The other physico-chemical characteristics of the wastes were determined as follows: the distribution of fractions in the $\mathrm{H}$ sample was $26 \pm 2 \%$ asphaltenes, $23 \pm 1 \%$ resins, $19 \pm 1 \%$ aliphatics, and $32 \pm 2 \%$ aromatics. EC in this sample was estimated to be $4.78 \pm 0.56$, and the $\mathrm{pH}$ was $7.2 \pm 10.1$. The $\mathrm{C}: \mathrm{N}$ ratio was equal to 187 (TOC $747 \pm 32, \mathrm{~N}_{\text {tot }}$ $\left.4 \pm 0.2 \mathrm{~g} \mathrm{~kg}^{-1}\right)$.

The treatment of the $H$-sample decreased the TPH content to $1.6 \pm 0.2 \mathrm{~g} \mathrm{~kg}^{-1}$ (Table 1) and increased the activity concentrations of ${ }^{226} \mathrm{Ra},{ }^{232} \mathrm{Th}$, and ${ }^{40} \mathrm{~K} 1.8-$, 1.4-, and 1.8fold, respectively; these values are comparable with those reported by El Afifi and Awwad, (2005); Bakr, (2010); AlSaleh and Al-Harshan, (2008); Abo-Elmagd et al., (2010). ${ }^{226} \mathrm{Ra}$ was the predominant isotope at $4.40 \pm 0.31 \mathrm{kBq} \mathrm{kg}^{-1}$. ${ }^{226} \mathrm{Ra}$ belongs to the uranium and thorium decay series, and the awareness of radium isotopes is caused by the fact that it decays into radon $\left({ }^{222} \mathrm{Rn}\right)$, which is a Class A carcinogen (Zakeri et al., 2012). A comparison of the results with the recommended IAEA levels for natural radionuclides (IBSS, 2001) indicated that the waste samples could cause environmental changes, as the values were 2.1- to 2.8-fold higher than recommended for ${ }^{232} \mathrm{Th}$ and 1.3 - to 2.3 -fold lower than recommended for ${ }^{226} \mathrm{Ra}$. Zakeri et al., (2012) reported that stress of $6 \mathrm{kBq}$ or more from ${ }^{226} \mathrm{Ra}$ influences growth characteristics, and stress of $1 \mathrm{kBq}$ or more up-regulates proteins in a Serratia marcescens strain isolated from a hot spring. In the $R$ sample we observed the following fractions in TPH: $36 \pm 3 \%$ asphaltenes, $33 \pm 2 \%$ resin, $12 \pm 1 \%$ aliphatics, and $19 \pm 12 \%$ aromatics. The electroconductivity of this sample was equal to $5.13 \pm 0.4$, the $\mathrm{pH}$ was $7.1 \pm 0.1$, and the $\mathrm{C}: \mathrm{N}$ ratio was 35 (TOC: $2.10 \pm 0.2 ; \mathrm{N}_{\text {tot }}$ : $0.06 \pm 0.01 \mathrm{~g} \mathrm{~kg}^{-1}$ ).

\subsection{Chemical characteristics of the soil samples}

The oil waste sample $H$ and its treated variant $R$ were added to the soil columns once, and then over 30 days an amount of water equal to the yearly local precipitation was added. In control columns, the TPH content and activity concentration of radioactive elements were typical for the natural soils (Starkov and Migunov, 2003; Vera Tomé et al., 2002; Shawky et al., 2001; Gumerova et al., 2013), and did not change significantly between the upper $(0-20 \mathrm{~cm})$, middle $(20-40 \mathrm{~cm})$, and lower $(40-60 \mathrm{~cm})$ layers. The TPH content ranged from 0.2 to $0.4 \mathrm{~g} \mathrm{~kg}^{-1}$, the activity concentration of ${ }^{226} \mathrm{Ra}$ ranged from 0.01 to 0.02 , that of ${ }^{232} \mathrm{Th}$ ranged from 0.021 to 0.023 , and that of ${ }^{40} \mathrm{~K}$ ranged from 0.29 to $0.34 \mathrm{kBq} \mathrm{kg}^{-1}$; these values are within the worldwide averages (UNSCEAR, 2000).

Higher TPH and radionuclide content values were seen for $H$ - and $R$-columns in comparison to corresponding controls (Fig. 1), which indicated leaching of toxic compounds from the waste samples into soil layers. $H$ waste samples increased the TPH content in $H$-soil columns, which was not observed for $R$-columns. In the Hu samples, TPH content was estimated to be 3.5 -fold higher than in the corresponding control $(\mathrm{Nu})$, while lesser amounts of hydrocarbons had migrated into the middle and lower soil layers (2.8- and 2.2fold greater than control). The trend for TPH distribution in soil layers indicated that TPH contamination of deeper soil layers was to be expected.

Analyses of radionuclide activity concentrations indicated that concentrations of ${ }^{40} \mathrm{~K}$ in the soil samples of $H$ - and $R$ columns did not differ from control values. In soil, this natural radioactive element predominated, and the concentration was not high in the waste samples. The average migration of other elements did not exceed $0.8 \%$. Presumably, the leakage of ${ }^{40} \mathrm{~K}$ from waste samples was comparable with that of other radionuclides, and therefore its migration did not change the natural level of this radionuclide in soil samples. 


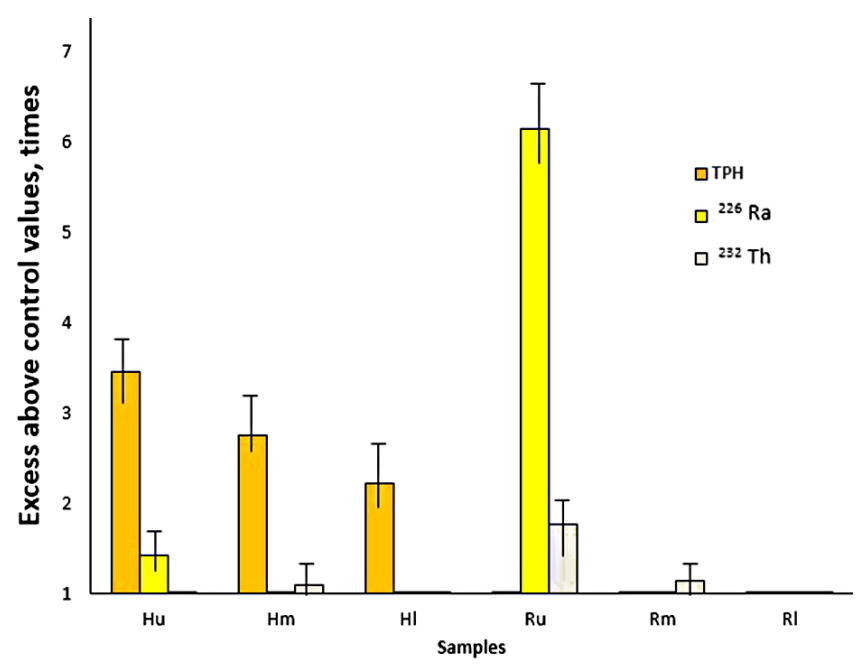

Figure 1. FExcess TPH content and activity concentrations of radionuclides in soil sampled from $H$-columns (contaminated by the raw waste containing oily compounds and radionuclides) and $R$ columns (contaminated by treated waste containing mainly radionuclides) in different layers [upper $(0-20 \mathrm{~cm} ; u)$, middle $(20-40 \mathrm{~cm}$; $m$ ), and lower $(40-60 \mathrm{~cm} ; l)]$ above the corresponding values of the control columns.

Activity concentrations of ${ }^{226} \mathrm{Ra}$ and ${ }^{232} \mathrm{Th}$ were increased in $H$-soil samples and 1.2- to 6.2-fold in $R$-soil samples over the control. The activity concentrations of these two elements were much higher in Ru- and Rm-samples compared to Hu- and Hm-samples, despite the fact that the amount of waste added to the columns was equalized with respect to the activity concentrations of radionuclides. Likely, radionuclides in raw waste samples were part of organic complexes, which hindered their leakage into soil layers with precipitation, while radionuclides migrated freely with water in the $R$ mineral sample.

Overall, it was shown that only low amounts (up to $0.8 \%$ ) of TPH and radionuclides leaked into soil. But these relatively low concentrations did alter the microbial community of soil as shown below.

\subsection{Microbial community in soil samples}

\subsubsection{Soil metabolic quotient, cellulase, and dehydrogenase activities}

Soil metabolic quotients $\left(q \mathrm{CO}_{2}\right)$, which were expected to be higher in the soil samples with higher microbial stress (Marin et al., 2005), are presented in Fig. 2a. The lowest $q \mathrm{CO}_{2}$ was observed for the upper and middle layers of the control columns, while the highest values were found for the upper and middle layers of the $H$-columns and in the lower layers of all three columns, where the microbial community was affected by oxygen and organic matter limitations. The first is probably due to the effects of hydrocarbons leached from the oil wastes on microorganisms.

Cellulases are important enzymes in the carbon cycle, and CA may be used to indicate soil impacts (Sinegani and Sinegani, 2012). As shown in Fig. 2b, CA in all soil columns decreased from the upper to the lower layers. No significant differences were found between $R$-samples and corresponding control samples, but in $\mathrm{Hu}$ and $\mathrm{Hm}$ samples, CA was 1.4-fold lower than that of the controls, which indicated that hydrocarbons can decrease the cellulase activity of the soil.

DHA is often used as a parameter for the estimation of soil quality, in particular for the hydrocarbon degradation rate (Margesin et al., 2000; Marin et al., 2005). In this study, no significant correlation between DHA and the toxic element content or soil depth was found for $R$ - and $H$-samples (from all three layers; Fig. 2c). This disagreed with the results reported in Lee et al., (2008) and Tejada et al., (2008), where a significant negative correlation between TPH content in soil and DHA was seen. However, these authors worked with soils containing $4.5-100 \mathrm{~g} \mathrm{~kg}^{-1}$ of hydrocarbons, whereas in this study, TPH levels did not exceed $1.3 \mathrm{~g} \mathrm{~kg}^{-1}$.

Microbial parameter values for $H$ - and $R$-columns were $62,70,95$, and $80,95,110 \%$ of corresponding control samples for the upper, middle, and lower layers, respectively. These data indicated that the highest stress existed in $\mathrm{Hu}$ and Hm samples, which were influenced by the raw waste. Radionuclides appeared to play a less important role for microbial functional properties.

\subsubsection{Microbial community structure}

Shifts in microbial community structure are sensitive indicators for assessing the changes in soils under the influence of pollution as well as other biotic and abiotic factors. Recently, culture-independent methods were used to estimate the number of strains belonging to different ecological or systematic groups (Adetutu et al., 2013). In this study, PCR-SSCP was used to describe the changes in microbial community structure (Schwieger and Tebbe, 1998).

\section{Bacterial species identified after sequencing of bands obtained from SSCP gels}

Total bacterial DNA was extracted, amplified by PCR using common bacterial primers for $16 \mathrm{~S}$ rDNA, and separated by polyacrylamide gel electrophoresis (SSCP profiles are shown in Fig. 3). SSCP patterns demonstrated variations between different soil layers and types of contaminants (oily components + radionuclides or only radionuclides), where 21 to 34 discrete bands of various intensities were observed for each SSCP line, and the types of bands were identified using relative electrophoretic distances. In total, 488 bands were detected and 25 were observed in at least two independent SSCP profiles. 
A

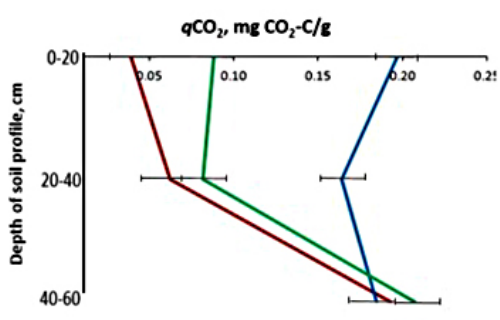

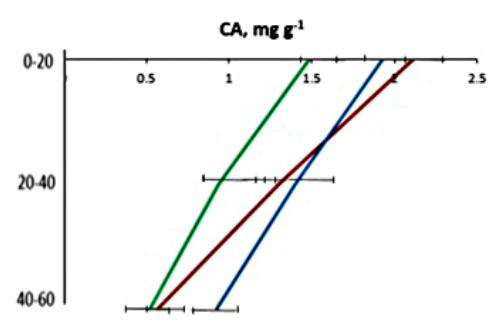

C

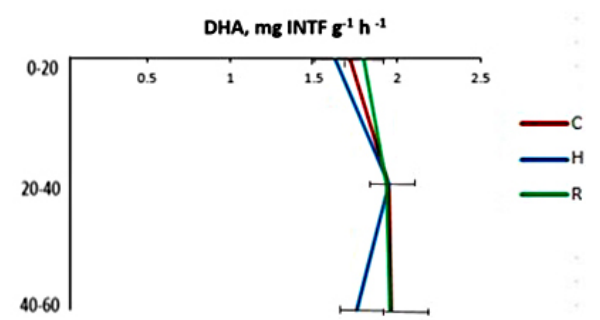

Figure 2. Microbial characteristics of the soil sampled from columns $C$ (uncontaminated soil), $H$ (contaminated by the raw waste containing oily compounds and radionuclides), and $R$ (contaminated by treated waste containing mainly radionuclides) in different layers [upper ( 0 $20 \mathrm{~cm} ; u)$, middle $(20-40 \mathrm{~cm} ; m)$, and lower $(40-60 \mathrm{~cm} ; l)] . A-$ metabolic quotient $\left(q \mathrm{CO}_{2}\right), B-$ cellulase activity $(\mathrm{CA}), C-$ dehydrogenase activity (DHA).

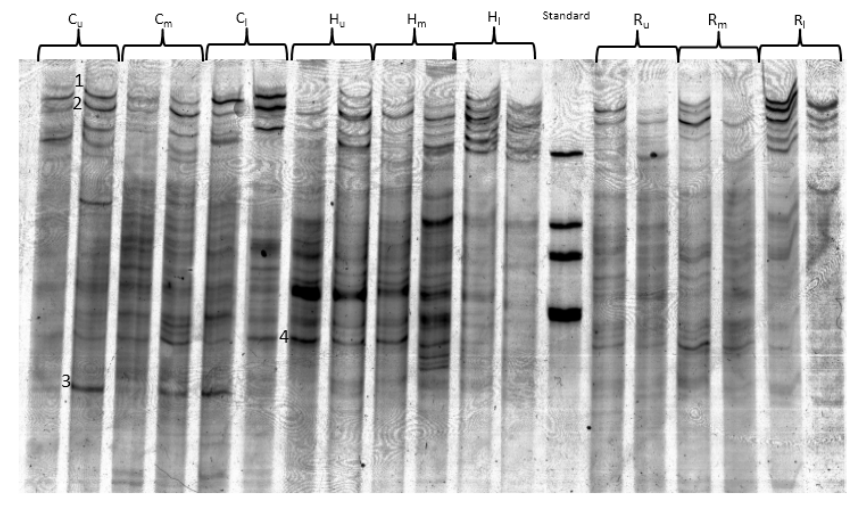

Figure 3. SSCP profiles of the bacterial communities of soil sampled from columns $C$ (uncontaminated soil), $H$ (contaminated by the raw waste containing oily compounds and radionuclides), and $R$ (contaminated by treated waste containing mainly radionuclides) in different layers [upper $(0-20 \mathrm{~cm} ; u)$, middle $(20-40 \mathrm{~cm} ; m)$, and lower $(40-60 \mathrm{~cm} ; l)]$.

Selected bands 1-4 (Fig. 3) were excised from the gel, cleaned, cloned, and sequenced. Bands 1 and 2 were considered stable, as they were present in all samples (except $\mathrm{Ru}$ ) in relatively large amounts. Band 3 dominated in control samples, and its relative abundance expressed in terms of area and band intensity was 1.5 - to 3.8-fold higher in control samples than in $H$ - and $R$-samples. Band 4 was present in all samples, but was predominant in $H$-samples.

Four randomly-picked clones of each band (after bluewhite selection) were sequenced, and the next relatives were identified by a similarity matrix using the neighbourjoining algorithm implemented in the ARB software and the SILVA database SSU 106 Ref. Clones of band 1 (KF926419KF926422) were phylogenetically similar to Burkholderia strains found in unpolluted and polluted sites (AF247491, DQ465451, FJ210816; Weisskopf et al., 2011; Friedrich et al., 2000), while clones of band 2 (KF926423-926425) were similar to strains of Burkholderia and Bradyrhizobium jicamae (JX010967, JN662515). Bacteria from the

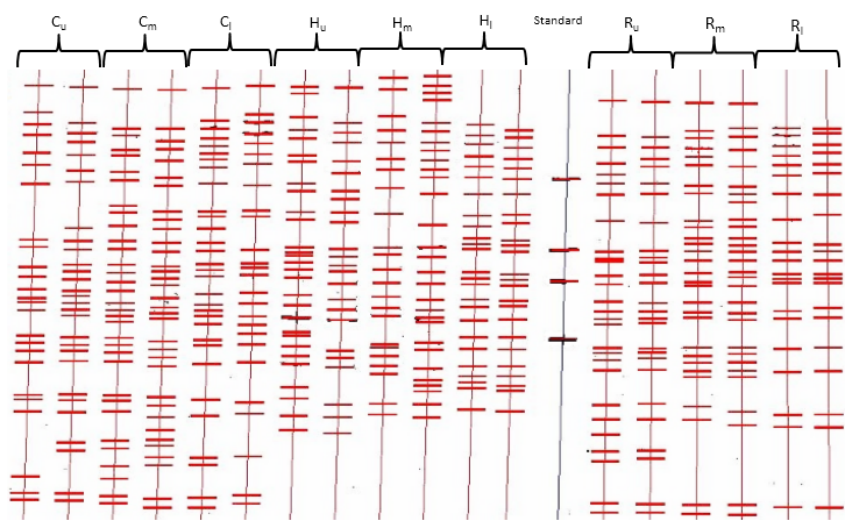

Figure 3. Continued.

genus Burkholderia are typical soil inhabitants, and certain Burkholderia strains are resistant to hydrocarbons and are used in the bioremediation of oil-polluted sites (Bacosa et al., 2012; Weisskopf et al., 2011; Hamamura et al., 2008; Adetutu et al., 2013). Band 3 (KF926426-KF926429), which is sensitive to oily and radioactive components in the waste samples (not seen in contaminated $H$ - and $R$-samples), was genetically similar to Hydrogenobacter hydrogenophilus (Z30242) uncultured Acidobacteria isolated from unpolluted grassland and forest soils (HQ598830, HQ599021; Naether et al., 2012) and an uncultured Chlorobiales bacterium found in a uranium mining waste pile (AJ295649, AJ536877; Selenska-Pobell, 2002). Band 4 (KF926430KF926433), which dominated in $H$-columns, was related to an uncultured bacterium from mineral soils of the Atacama desert (JX098489, JX098426; Lynch et al., 2012) and actinomycetes from the genus Catenulispora (CP001700, AJ865857; Busti et al., 2006) as well as strains isolated from gasoline-polluted sites (or able to degrade hydrocarbons; JQ919514; Hilyard et al., 2008), including a Parvibaculum strain that catabolizes linear alkylbenzene sulfonate (AY387398; Schleheck et al., 2004). 
Table 2. The biodiversity indices of the soil sampled from the upper $(u)$, middle $(m)$, and lower $(l)$ layers of the control $(C)$, raw waste $(H)$, and treated waste $(R)$ contaminated columns.

\begin{tabular}{lrrrrr}
\hline Samples & $S$ & $I$ & $H$ & $D$ & $E$ \\
\hline $\mathrm{Cu}$ & 25 & 0.74 & 3.01 & 0.94 & 0.93 \\
$\mathrm{Cu}$ & 29 & 0.85 & 3.05 & 0.94 & 0.90 \\
$\mathrm{Cm}$ & 33 & 0.97 & 3.31 & 0.96 & 0.95 \\
$\mathrm{Cm}$ & 34 & 1.00 & 3.38 & 0.96 & 0.96 \\
$\mathrm{Cl}$ & 31 & 0.91 & 3.19 & 0.95 & 0.93 \\
$\mathrm{Cl}$ & 26 & 0.76 & 2.91 & 0.93 & 0.89 \\
$\mathrm{Hu}$ & 29 & 0.85 & 2.80 & 0.89 & 0.83 \\
$\mathrm{Hu}$ & 24 & 0.71 & 2.79 & 0.91 & 0.88 \\
$\mathrm{Hm}$ & 23 & 0.68 & 2.84 & 0.92 & 0.90 \\
$\mathrm{Hm}$ & 29 & 0.85 & 3.11 & 0.94 & 0.92 \\
$\mathrm{Hl}$ & 25 & 0.74 & 2.84 & 0.92 & 0.88 \\
$\mathrm{Hl}$ & 25 & 0.74 & 2.83 & 0.92 & 0.88 \\
$\mathrm{Ru}$ & 28 & 0.82 & 3.22 & 0.96 & 0.97 \\
$\mathrm{Ru}$ & 27 & 0.79 & 3.17 & 0.95 & 0.96 \\
$\mathrm{Rm}$ & 29 & 0.85 & 3.09 & 0.94 & 0.92 \\
$\mathrm{Rm}$ & 29 & 0.85 & 3.24 & 0.96 & 0.96 \\
$\mathrm{Rl}$ & 21 & 0.62 & 2.72 & 0.91 & 0.89 \\
$\mathrm{Rl}$ & 21 & 0.62 & 2.73 & 0.91 & 0.89 \\
\hline
\end{tabular}

$H$-index - Shannon-Weaver index, $D$-index - Simpson index, $S$-index - number of species (bands) in SSCP profile, $I$-index - simple index, $E$-index - Shannon's evenness (index of equitability of the bands).

\section{SSCP analysis of PCR products and statistical analysis}

The microbial diversity of each sample was calculated using five indices, and the results are presented in Table 2.

The $S$-index represented the number of SSCP bands in a line (in the sample). The number of bands ranged between 25 and 34 in $C$-columns, between 23 and 29 in $H$-columns, and between 21 and 29 in $R$-columns. No significant differences were seen between samples from $H, R$, and control columns with respect to depth. Only in the Rl-samples did the number of the SSCP patterns decrease significantly in comparison to samples from the upper and middle layers. The average number of bands tended to be higher in the control samples (29.7) compared to the contaminated samples (25.8 each). According to the data presented in the literature, the influence of combined hydrocarbon and mineral contamination of soil can lead to both increases and decreases in its microbial diversity. Thus, the increase of microbial diversity is explained by the fact that TPH can be used by microorganisms as carbon sources. Therefore, a relatively low TPH input could lead to the development of a new hydrocarbondegrading species without suppression of indigenous microbes (Gao et al., 2015; Nie et al., 2009). Negative effects on soil biodiversity are explained by significant inhibition of indigenous microflora in the oil-contaminated sites because of the toxic influence of hydrocarbons or their metabolites, oxygen deficit, and other factors (Hui et al., 2007; Morelli et al., 2005; Marcin et al., 2013).

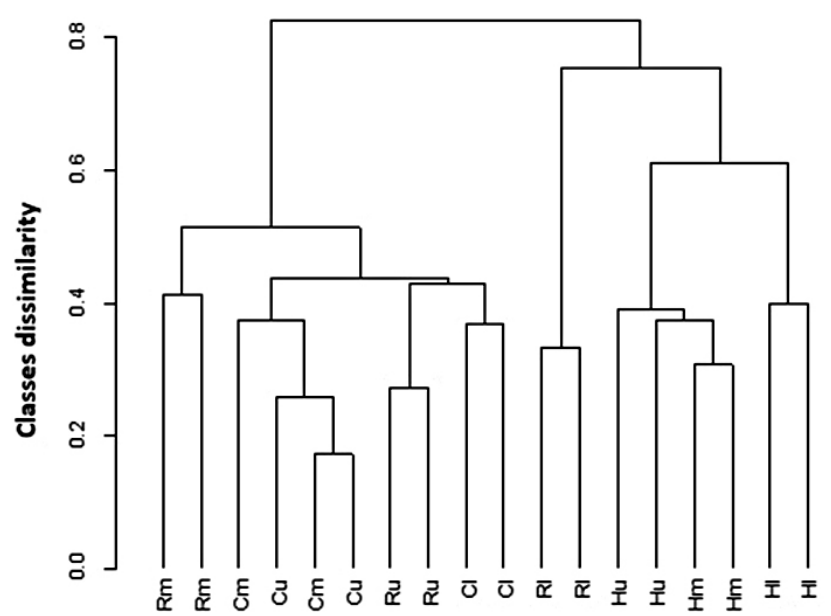

Figure 4. Cluster analysis of the SSCP bands observed on SSCP profiles of soil sampled from the columns $C$ (uncontaminated soil), $H$ (contaminated by the raw waste containing oily compounds and radionuclides), and $R$ (contaminated by treated waste containing mainly radionuclides) in different layers [upper $(0-20 \mathrm{~cm} ; u)$, middle $(20-40 \mathrm{~cm} ; m)$, and lower $(40-60 \mathrm{~cm} ; l)]$.

The $I$-index reflected the diversity of bands in the sample with respect to the sample with the highest biodiversity; the highest $I$-indices were observed in Cm samples and the lowest in Rl samples. The community diversity Shannon-Weaver index ( $H$-index), which is expected to be higher in samples with the highest number of bands but with similar frequencies, fluctuated from 2.72 to 3.38 . This reflected the variety of band profiles among samples, which indicated changes in the microbial community due to waste compounds or depth. The evenness ( $E$-index) was higher in the samples with higher $H$ indices $(R=0.86)$. The Simpson $D$-index was smaller when one band predominated, and the lowest $D$-indices were observed for Rl and Hu samples. The sample compositions differed significantly between $H$-samples and other samples, and the bands labelled 4 (Fig. 4) were dominant while band 3 disappeared. These results were in agreement with those of Morelli et al. (2005), who observed that organisms in polluted ecosystems which are capable of degrading contaminants or resisting toxicity are dominant, while other species do not survive.

The ANOVA of the linear model of influence of factors (type of waste, depth, their interdependence, and residuals) on biodiversity was performed. The presence of oil waste was significant only for the $D$-index $(p<0.01)$, while other indices of biodiversity did not depend on the factors investigated.

The correlation between factors describing soil samples (type of waste, depth, their interdependence, and residuals) and microbial community structure was examined. ANOVA of the presence or absence of 25 bands (which were observed in at least two samples) was carried out, and it was found that depth was a significant factor for five bands, the presence of 
contaminant for six, and the combined influence of these two factors for three $(p<0.01)$. An ANOVA for the MDS values was performed as suggested by Lin et al., (2012) to reduce the dimensions of the values analysed. The type of waste, as well as the interaction between waste and depth, was significant for the structure of the microbial community. Depth did not play an important role in the bacterial community structure $(p<0.01)$ and the control columns did not differ between soil layers, as opposed to $H$ - and $R$-columns.

Samples were grouped using MDS and clustering analysis methods. Cluster analysis, which orders samples according to their similarity indices, is commonly used to show the differences or classification between groups of clusters (Kadali et al., 2012). To determine the number of clusters on the dendrogram (Fig. 4), the method of natural break was implemented. The samples were divided into two groups: the first group included all control samples, while the second group contained $R$-samples from the upper and middle layers as well as all $H$ - and $R$-samples from lower layers (the samples of the second group contained fewer microbial strains). The first group was subdivided into three parts according to the type of waste or depth: Rm-samples, C-samples of the upper and middle layers (further subdivided into Rl-samples, Hl-samples, and $H$-samples of the upper and middle layers), and $\mathrm{Ru} / \mathrm{Cl}$ samples.

MDS is the most common ordination method used for ecological community data (Wilson et al., 2013; Terahara et al., 2004). Figure 5 shows the MDS plot ( $r^{2}=0.56$ for distance correspondence), where the closer to one another the points representing microbial communities were situated on the plot, the more similar these microbial communities were. Samples were positioned according to the type of contaminant $(H, R$, and uncontaminated control, $C)$, which could be explained by the selective influence of toxic compounds from $H$ and $R$ on the strains present in soil. This finding is consistent with that of Hamamura et al. (2008), who suggested that the population shifts corresponding to the prominent bands in soils are due to the content of hydrocarbons. It is important to note that communities from the $R$-columns were separated from the communities from $\mathrm{C}$-columns, despite the fact that the activity concentration of ${ }^{226} \mathrm{Ra}$ was below the recommended level (IBSS, 2001) and not in line with the estimates for functional characteristics of the microbial community. This confirmed that PCR-based estimates of environmental influence can be more sensitive than traditional methods (Lin et al., 2012; Bialek et al., 2011).

\section{Conclusions}

Oil wastes generated during processing, transportation, and refining of petroleum, which are frequently disposed on the soil surface, are serious environmental threats, especially in petroleum-producing regions. In this study, we have investigated the combined effects of hydrocarbons and radionu-

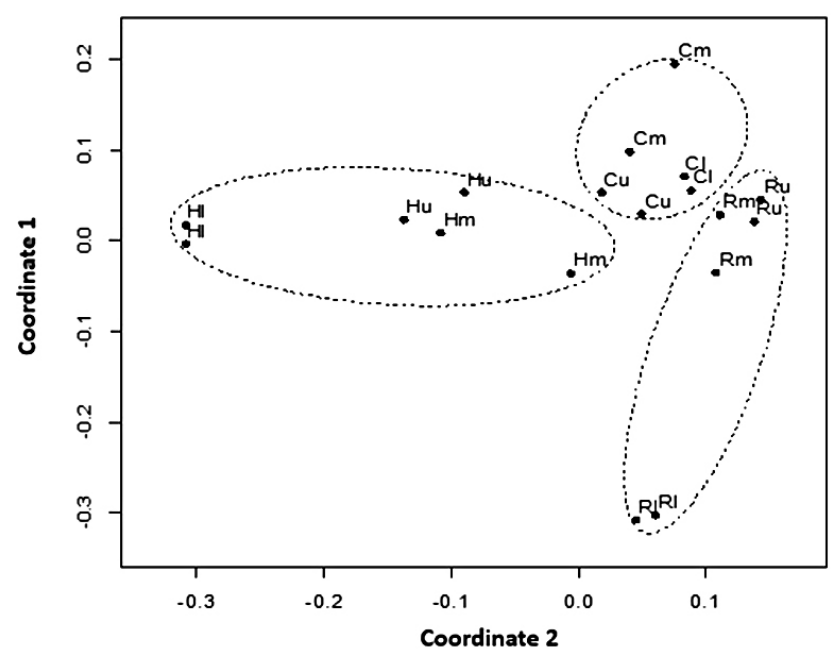

Figure 5. Metric multidimensional scaling analysis based on distance matrix of SSCP profiles of soil sampled from the columns $C$ (uncontaminated soil), $H$ (contaminated by the raw waste containing oily compounds and radionuclides), and $R$ (contaminated by treated waste containing mainly radionuclides) on different layers [upper $(0-20 \mathrm{~cm} ; u)$, middle $(20-40 \mathrm{~cm} ; m)$, and lower $(40-60 \mathrm{~cm}$; $l)]$.

clides contained in oil waste on the soil microbial community. Such effects have not been studied before, although a large amount of oil waste is radioactive. We analysed the wastes from tanks, pipes, and production equipment sampled in different seasons between 2010 and 2012 and established a wide range of TPH content from $1.6 \pm 0.2$ to $880.3 \pm 176.8 \mathrm{~g} \mathrm{~kg}^{-1}$, activity concentration of ${ }^{226} \mathrm{Ra}$ from $0.03 \pm 0.01$ to $7.92 \pm 0.93$, activity concentration of ${ }^{232} \mathrm{Th}$ from $0.02 \pm 0.01$ to $5.09 \pm 1.02$, and activity concentration of ${ }^{40} \mathrm{~K}$ from $0.03 \pm 0.01$ to $2.28 \pm 0.34 \mathrm{kBq} \mathrm{kg}^{-1}$. To distinguish between the effects of hydrocarbons and radionuclides, we chose the raw waste $H$ with a typical content of TPH and radionuclides and its treated variant with reduced hydrocarbon content but containing radionuclides (waste $R$ ).

The sample $H$ contained $4.40 \pm 0.31 \mathrm{kBq} \mathrm{kg}^{-1}$ of ${ }^{226} \mathrm{Ra}$, $2.85 \pm 0.21 \mathrm{kBq} \mathrm{kg}^{-1}$ of ${ }^{232} \mathrm{Th}$, and $575.2 \pm 121.0 \mathrm{~g} \mathrm{~kg}^{-1}$ of TPH and the sample $R$ contained $7.9 \pm 1.8 \mathrm{kBq} \mathrm{kg}^{-1}$ of ${ }^{226} \mathrm{Ra}, 3.9 \pm 0.9 \mathrm{kBq} \mathrm{kg}^{-1}$ of ${ }^{232} \mathrm{Th}$, and $1.6 \pm 0.4 \mathrm{~g} \mathrm{~kg}^{-1}$ of TPH. The last two compounds exceeded the levels reported to be non-toxic in the environment, indicating that the traditional practice where oil waste was spread on the soil surface could have negative effects on the soil.

Disposal of $H$ waste samples on the soil surface increased the TPH content in $H$-soil columns, which was not observed for $R$-columns. In the soil sampled from the upper layer of the $H$-column, the TPH content was estimated to be 3.5fold higher than in the corresponding control sample, while lesser amounts of hydrocarbons had migrated into the middle and lower soil layers (2.8 and 2.2 times higher than control). Despite the fact that the amount of waste samples disposed 
of on the tops of soil columns was equalized according to the amount of ${ }^{226} \mathrm{Ra}$, a greater amount of this radionuclide was observed in the soil of $R$-columns: it was 4.3, 1.4, and 1.2 times higher than that in $H$-columns in the upper, middle, and lower layers, respectively. It is likely that radionuclides in raw waste samples were part of organic complexes which hindered their leakage into soil layers with precipitation, while radionuclides migrated freely with water in the $R$ mineral sample.

By analysing the functional characteristics of soil microorganisms, oil compounds (but not radionuclides) were found to influence soil microflora. The $q \mathrm{CO}_{2}$ and cellulase activity in soil samples from $H$-columns were reduced 1.3 to 2.2 times more than in $R$-columns, where microbial activity values were close to the control values. In contrast, PCR-SSCP demonstrated that both oil compounds and radioactive elements could cause shifts in the microbial community structure.

We conclude that oil waste containing radioactive elements caused negative changes of soil microbial community by its disposal, while petroleum hydrocarbons played the more pronounced negative role. The effects of radionuclides contained in oily waste on soil can be evaluated using culture-independent analyses of microbial communities.

Acknowledgements. This work was funded by the subsidy allocated to the Kazan Federal University for the state assignment in the sphere of scientific activities.

Edited by: Y. Kuzyakov

\section{References}

Abo-Elmagd, M., Soliman, H. A., Salman Kh, A., and El-Masry, N. M.: Radiological hazards of TENORM in the wasted petroleum pipes, J. Environ. Radioactiv., 101, 51-54, 2010.

Adetutu, E. M., Smith, R. J., Weber, J., Aleer, S., Mitchell, J. G., Ball, A. S., and Juhasz, A. L.: A polyphasic approach for assessing the suitability of bioremediation for the treatment of hydrocarbon-impacted soil, Sci. Total Environ., 450, 51-58, 2013.

Admon, S., Green, M., and Avnimelech, Y.: Biodegradation kinetics of hydrocarbons in soil during land treatment of oily sludge, Biorem. J., 5, 193-209, 2001.

Al-Futaisi, A., Jamrah, A., Yaghi, B., and Taha, R.: Assessment of alternative management techniques of tank bottom petroleum sludge in Oman, J. Hazard. Mater., 141, 557-564, doi:10.1016/j.jhazmat.2006.07.023, 2007.

Al-Masri, M. S., Aba, A., Al-Hamwi, A., and Shakhashiro, A.: Preparation of in-house reference soil sample containing high levels of naturally occurring radioactive materials from the oil industry, Applied radiation and isotopes: including data, instrumentation and methods for use in agriculture, industry and medicine, 1397-1402, 2004.
Al-Saleh, F. S. and Al-Harshan, G. A.: Measurements of radiation level in petroleum products and wastes in Riyadh City Refinery, J. Environ. Radioactiv., 99, 1026-1031, 2008.

Anderson, T. H., and Domsch, K. H.: Application of ecophysiological quotients $\left(q \mathrm{CO}_{2}\right.$ and $\left.\mathrm{qD}\right)$ on microbial biomasses from soils of different cropping histories, Soil Biol. Biochem., 22, 251-255, 1990.

Ashelford, K. E., Chuzhanova, N. A., Fry, J. C., Jones, A. J., and Weightman, A. J.: At least 1 in 20 16S rRNA sequence records currently held in public repositories is estimated to contain substantial anomalies, Appl. Environ. Microbiol., 71, 7724-7736, 2005.

Ayotamuno, M. J., Okparanma, R. N., Nweneka, E. K., Ogaji, S. O. T., and Probert, S. D.: Bio-remediation of a sludge containing hydrocarbons, Appl. Energy, 84, 936-943, 2007.

Bacosa, H. P., Suto, K., and Inoue, C.: Bacterial community dynamics during the preferential degradation of aromatic hydrocarbons by a microbial consortium, Int. Biodeter. Biodegr., 74, 109-115, 2012.

Bakr, W. F.: Assessment of the radiological impact of oil refining industry, J. Environ. Radioactiv., 101, 237-243, 2010.

Bialek, K., Kim, J., Lee, C., Collins, G., Mahony, T., and O'Flaherty, V.: Quantitative and qualitative analyses of methanogenic community development in high-rate anaerobic bioreactors, Water Res., 45, 1298-1308, 2011.

Busti, E., Monciardini, P., Cavaletti, L., Bamonte, R., Lazzarini, A., Sosio, M., and Donadio, S.: Antibiotic-producing ability by representatives of a newly discovered lineage of actinomycetes, Microbiology-Sgm, 152, 675-683, 2006.

Chambers, J. M., and Hastie, T. J.: Statistical Models in S, Wadsworth \& Brooks/Cole, 624 pp., 1992.

El Afifi, E. M. and Awwad, N. S.: Characterization of the TENORM waste associated with oil and natural gas production in Abu Rudeis, Egypt, J. Environ. Radioactiv., 82, 7-19, 2005.

Faith, D. P., Minchin, P. R., and Belbin, L.: Compositional dissimilarity as a robust measure of ecological distance, Vegetatio, 69, 57-68, 1987.

Felsenstein, J.: PHYLIP - Phylogeny Inference Package (Version 3.2), Cladistics, 5, 164-166, 1989.

Fotiou, F., Goulas, A., Fountoulakis, K., Koutlas, E., Hamlatzis, P., and Papakostopoulos, D.: Changes in psychophysiological processing of vision in myasthenia gravis, International journal of psychophysiology : official journal of the International Organization of Psychophysiology, 29, 303-310, 1998.

Friedrich, M., Grosser, R. J., Kern, E. A., Inskeep, W. P., and Ward, D. M.: Effect of model sorptive phases on phenanthrene biodegradation: Molecular analysis of enrichments and isolates suggests selection based on bioavailability, Appl. Environ. Microbiol., 66, 2703-2710, 2000.

Galitskaya, P. Y., Gumerova, R. K., and Selivanovskaya, S. Y.: Bioremediation of oil waste under field experiment, World Appl. Scien. J., 30, 1694-1698, 2014.

Gao, Y-ch., Wang J-n., Guo, Sh-h., Hu, Y-L., Li T-t., Mao, R., and Zeng, D-H.: Effects of salinization and crude oil contamination on soil bacterial community structure in the Yellow River Delta region, China. Appl. Soil Ecol., 86, 165-173, 2015.

Garcia, C., Hernandez, T., and Costa, F.: Potential use of dehydrogenase activity as an index of microbial activity in degraded soils, Commun. Soil Sci. Plan., 28, 123-134, 1997. 
Gazineu, M. H. and Hazin, C. A.: Radium and potassium-40 in solid wastes from the oil industry, Appl. Radiat. Isot., 66, 90-94, 2008.

Gumerova, R. K., Galitskaya, P. Y., Badrutdinov, O. R., and Selivanovskaya, S. Y.: Changes of hydrocarbon and oil fractions contents in oily waste treated by different methods of bioremediation, Neftyanoe Khozyaistvo - Oil Industry, 118-120, 2013.

Hamamura, N., Fukui, M., Ward, D. M., and Inskeep, W. P.: Assessing Soil Microbial Populations Responding to CrudeOil Amendment at Different Temperatures Using Phylogenetic, Functional Gene (alkB) and Physiological Analyses, Environ. Sci. Technol., 42, 7580-7586, 2008.

Hamlat, M. S., Djeffal, S., and Kadi H.: Assessment of radiation exposures from naturally occurring radioactive materials in the oil and gas industry, Applied radiation and isotopes: including data, instrumentation and methods for use in agriculture, industry and medicine, 141-146, 2001.

Hilyard, E. J., Jones-Meehan, J. M., Spargo, B. J., and Hill, R. T.: Enrichment, isolation, and phylogenetic identification of polycyclic aromatic hydrocarbon-degrading bacteria from Elizabeth River sediments, Appl. Environ. Microbiol., 74, 1176-1182, 2008.

Hrichi, H., Baccouche, S., and Belgaied, J. E.: Evaluation of radiological impacts of tenorm in the Tunisian petroleum industry, J. Environ. Radioactiv., 115, 107-113, 2013.

$\mathrm{Hu}$, G., Lia, J., Zeng, G. Recent development in the treatment of oily sludge from petroleum industry: A review, J. Hazard. Mater., 261, 470-490, 2013.

Huang, J., Li, Z., Zeng, G., Zhang, J., Li, J., Nie, X., Ma, W., and Zhang, X.: Microbial responses to simulated water erosion in relation to organic carbon dynamics on a hilly cropland in subtropical China, Ecol. Engin., 60, 65-75, 2013.

Hui, L., Zhang, Y., Kravchenko, I., Hui, X., and Zhang, C.-G.: Dynamic changes in microbial activity and community structure during biodegradation of petroleum compounds: A laboratory experiment, J. Environ. Sci.-China, 19, 1003-1013, 2007.

IBSS: IAEA 115-1, in: Safety Series, International Basic Safety Standards, Vienna, 17 pp., 2001.

ISO 11265:1994: Soil quality - Determination of the specific electrical conductivity; International Organization for Standardization, 4 pp., 1994.

ISO 10694:1995: Soil quality - Determination of organic and total carbon after dry combustion (elementary analysis); International Organization for Standardization, 7 pp., 1995.

ISO 11261:1995: Soil quality - Determination of total nitrogen Modified Kjeldahl method; International Organization for Standardization, 4 pp., 1995.

ISO 14240-2: Soil quality - Determination of soil microbial biomass - Part 2: Fumigation-extraction method; International Organization for Standardization, 4 pp., 1997.

Kadali, K. K., Simons, K. L., Skuza, P. P., Moore, R. B., and Ball, A. S.: A complementary approach to identifying and assessing the remediation potential of hydrocarbonoclastic bacteria, J. Microbiol. Meth., 88, 348-355, 2012.

Kampmann, K., Ratering, S., Kramer, I., Schmidt, M., Zerr, W., and Schnell, S.: Unexpected Stability of Bacteroidetes and Firmicutes Communities in Laboratory Biogas Reactors Fed with Different Defined Substrates, Appl. Environ. Microbiol., 78, 21062119, 2012.
Labud, V. G. C. and Hernandez, T.: Effect of hydrocarbon pollution on the microbial properties of a sandy and a clay soil, Chemosph., 66, 1863-1871, 2007.

Lamy, E., Tran, T. C., Mottelet, S., Pauss, A., and Schoefs, O.: Relationships of respiratory quotient to microbial biomass and hydrocarbon contaminant degradation during soil bioremediation, Int. Biodeter. Biodegrad., 83, 85-91, 2013.

Lazar, I., Dobrota, S., Voicu, A., Stefanescu, M., Sandulescu, L., and Petrisor, I. G.: Microbial degradation of waste hydrocarbons in oily sludge from some Romanian oil fields, J. Petrol. Scien. Engin., 22, 151-160, 1999.

Lee, S. H., Oh, B. I., and Kim, J. G.: Effect of various amendments on heavy mineral oil bioremediation and soil microbial activity, Biores. Technol., 99, 2578-2587, 2008.

Li, F., Liu, M., Li, Z., Jiang, C., Han, F., and Che, Y.: Changes in soil microbial biomass and functional diversity with a nitrogen gradient in soil columns, Appl. Soil Ecol., 64, 1-6, 2013.

Lin, J., Zuo, J. E., Ji, R. F., Chen, X. J., Liu, F. L., Wang, K. J., and Yang, Y. F.: Methanogenic community dynamics in anaerobic codigestion of fruit and vegetable waste and food waste, J. Environ. Sci.-China, 24, 1288-1294, 2012

Liu, P. W. G., Chang, T. C., Chen, C. H., Wang, M. Z., and Hsu, H. W.: Effects of soil organic matter and bacterial community shift on bioremediation of diesel-contaminated soil, Int. Biodeter. Biodegrad., 85, 661-670, 2013.

Liu, W. X., Luo, Y. M., Teng, Y., Li, Z. G., and Christie, P.: Prepared bed bioremediation of oily sludge in an oilfield in northern China, J. Hazard. Mater., 161, 479-484, 2009.

Ludwig, W., Strunk, O., Westram, R., Richter, L., Meier, H., Yadhukumar, Buchner, A., Lai, T., Steppi, S., Jobb, G., Forster, W., Brettske, I., Gerber, S., Ginhart, A. W., Gross, O., Grumann, S., Hermann, S., Jost, R., Konig, A., Liss, T., Lussmann, R., May, M., Nonhoff, B., Reichel, B., Strehlow, R., Stamatakis, A., Stuckmann, N., Vilbig, A., Lenke, M., Ludwig, T., Bode, A., and Schleifer, K. H.: ARB: a software environment for sequence data, Nucleic Acids Res., 32, 1363-1371, 2004.

Lynch, R. C., King, A. J., Farias, M. E., Sowell, P., Vitry, C., and Schmidt, S. K.: The potential for microbial life in the highestelevation (> 6000 m.a.s.l.) mineral soils of the Atacama region, $\mathrm{J}$. Geophys. Res.-Biogeosci., 117, 2012.

Marcin, C., Marcin, G., Justyna, M. P., Katarzyna, K., and Maria, N.: Diversity of microorganisms from forest soils differently polluted with heavy metals, Appl. Soil Ecol., 64, 7-14, 2013.

Margesin, R., Zimmerbauer, A., and Schinner, F.: Monitoring of bioremediation by soil biological activities, Chemosphere, 40, 339-346, 2000.

Marin, J. A., Hernandez, T., and Garcia, C.: Bioremediation of oil refinery sludge by landfarming in semiarid conditions: Influence on soil microbial activity, Environ. Res., 98, 185-195, 2005.

Mikkonen, A., Hakala, K. P., Lappi, K., Kondo, E., Vaalama, A., and Suominen, L.: Changes in hydrocarbon groups, soil ecotoxicity and microbiology along horizontal and vertical contamination gradients in an old landfarming field for oil refinery waste, Environ. Pollution, 162, 374-380, 2012.

Min, J., Lee Ch. W., and Gu M. B.: Gamma-radiation dose-rate effects on DNA damage and toxicity in bacterial cells, Radiat. Environ. Bioph., 42, 189-192, 2003.

Mishra, S., Jyot, J., Kuhad, R. C., and Lal, B.: Evaluation of inoculum addition to stimulate in situ bioremediation of oily-sludge- 
contaminated soil, Appl. Environ. Microbiol., 4, 1675-1681, 2001.

Morelli, I. S., Del Panno, M. T., De Antoni, G. L., and Painceira, M. T.: Laboratory study on the bioremediation of petrochemical sludge-contaminated soil, Int. Biodeter. Biodegrad., 55, 271278, 2005.

Naether, A., Foesel, B. U., Naegele, V., Wust, P. K., Weinert, J., Bonkowski, M., Alt, F., Oelmann, Y., Polle, A., Lohaus, G., Gockel, S., Hemp, A., Kalko, E. K. V., Linsenmair, K. E., Pfeiffer, S., Renner, S., Schoning, I., Weisser, W. W., Wells, K., Fischer, M., Overmann, J., and Friedrich, M. W.: Environmental Factors Affect Acidobacterial Communities below the Subgroup Level in Grassland and Forest Soils, Appl. Environ. Microbiol., 78, 7398-7406, 2012.

Nie, M., Zhang, X., Wang, J., Jiang, L., Yang, J., Quan, Z., Cui, X., Fang, C., and Li, B.: Rhizosphere effects on soil bacterial abundance and diversity in the Yellow River Deltaic ecosystem as influenced by petroleum contamination and soil salinization, Soil Biol. Biochem., 41, 2535-2542, 2009.

Pancholy, S. K. and Rice, E. L.: Soil enzymes in relation to old field succession: amylase, cellulase, invertase, dehydrogenase, and urease, Proceedings of American Soil Science Society, 37, 47-50, 1973.

Plaza, G., Nalecz-Jawecki, G., Ulfig, K., and Brigmon, R. L.: The application of bioassays as indicators of petroleum-contaminated soil remediation, Chemosphere, 59, 289-296, 2005.

Pruesse, E., Quast, C., Knittel, K., Fuchs, B. M., Ludwig, W. G., Peplies, J., and Glockner, F. O.: SILVA: a comprehensive online resource for quality checked and aligned ribosomal RNA sequence data compatible with ARB, Nucleic Acids Res., 35, 7188-7196, 2007.

R Development Core Team: R: A language and environment for statistical computing, R Foundation for Statistical Computing, Vienna, Austria, 2012.

Ros, M., Rodriguez, I., Garcia, C., and Hernandez, T.: Microbial communities involved in the bioremediation of an aged recalcitrant hydrocarbon polluted soil by using organic amendments, Biores. Technol., 101, 6916-6923, 2010.

Ruffing, A. M. and Trahan C. A.: Biofuel toxicity and mechanisms of biofuel tolerance in three model cyanobacteria, Algal Research, 5, 121-132, 2014.

Schinner, F., Ohlinger, R., Kandeler, E., and Margesin, R.: Methods in Soil Biology, Heidelberg: Springer-Verlag, Berlin, 418 pp., 1995.

Schleheck, D., Tindall, B. J., Rossello-Mora, R., and Cook, A. M.: Parvibaculum lavamentivorans gen. nov., sp nov., a novel heterotroph that initiates catabolism of linear alkylbenzenesulfonate, Int. J. System. Evolut. Microbiol., 54, 1489-1497, 2004.

Schwieger, F. and Tebbe, C. C.: A new approach to utilize PCRsingle-strand-conformation polymorphism for 16s rRNA genebased microbial community analysis, Appl. Environ. Microbiol., 64, 4870-4876, 1998.

Selenska-Pobell, S.: Diversity and activity of bacteria in uranium mining waste piles, Radioactiv. Environm., 22, 225-254, 2002.

Selivanovskaya, S. Y., Kuritsyn, I. N., Akhmetzynova, L. G., Galitskaya, P. Y., and Solovjev, D. A.: Use of biological activity index for determination of the oil polluted area meant for remediation, Neftynoe Khozyaistvo - Oil Industry, 102-103, 2012.
Selivanovskaya, S. Y., Gumerova, R. K., and Galitskaya, P. Y.: Assessing the efficiency of methods for the bioremediation of oil production wastes, Contemp. Probl. Ecol., 6, 542-548, 2013.

Shannon, C. E. and Weaver, W.: The mathematical theory of communication, Urbana, IS: University of Illinois Press, 125 pp., 1963.

Shawky, S., Amer, H., Nada, A. A., Abd el-Maksoud, T. M., and Ibrahiem, N. M.: Characteristics of NORM in the oil industry from Eastern and Western deserts of Egypt, Appl. Radiat. Isot., 55, 135-139, 2001.

Silvestri, G., Santarelli, S., Aquilanti, L., Beccaceci, A., Osimani, A., Tonucci, F., and Clementi, F.: Investigation of the microbial ecology of Ciauscolo, a traditional Italian salami, by culturedependent techniques and PCR-DGGE, Meat Science, 77, 413423, 2007.

Simpson, E. H.: Measurement of diversity, Nature, 163, 688, 1949.

Sinegani, A. A. S. and Sinegani, M. S.: The effects of carbonates removal on adsorption, immobilization and activity of cellulase in a calcareous soil, Geoderma, 173, 145-151, 2012.

Starkov, V. D. and Migunov, V. I.: Radiation ecology (in Russian), FGU IPP “Tumen”, Tumen (Russia), 304 pp., 2003.

Tahhan, R. A. and Abu-Ateih, R. Y.: Biodegradation of petroleum industry oily-sludge using Jordanian oil refinery contaminated soil, Intern. Biodeter. Biodegrad., 63, 1054-1060, 2009.

Tamura, K., Peterson, D., Peterson, N., Stecher, G., Nei, M., and Kumar, S.: MEGA5: Molecular Evolutionary Genetics Analysis Using Maximum Likelihood, Evolutionary Distance, and Maximum Parsimony Methods, Mol. Biol. Evol., 28, 2731-2739, 2011.

Tejada, M., Gonzalez, J. L., Hernandez, M. T., and Garcia, C.: Application of different organic amendments in a gasoline contaminated soil: Effect on soil microbial properties, Bioresource Technol., 99, 2872-2880, 2008.

Terahara, T., Hoshino, T., Tsuneda, S., Hirata, A., and Inamori, Y.: Monitoring the microbial population dynamics at the startup stage of wastewater treatment reactor by terminal restriction fragment length polymorphism analysis based on 16S rDNA and rRNA gene sequences, J. Bioscien. Bioengineer., 98, 425-428, 2004.

UNSCEAR: Sources and Effects of Ionizing Radiation. Scientific Committee on the Effects of Atomic Radiation, United Nations Scientific Committee on the Effects of Atomic Radiation, New York, 17, 2000.

Vera Tomé, F., Blanco Rodrìguez, P., and Lozano, J. C.: Distribution and mobilization of $\mathrm{U}, \mathrm{Th}$ and 226Ra in the plant-soil compartments of a mineralized uranium area in south-west Spain, J. Environ. Radioactiv., 59, 41-60, 2002.

Verma, S., Bhargava, R., and Pruthi, V.: Oily sludge degradation by bacteria from Ankleshwar, India, Int. Biodeterior. Biodegrad., 57, 207-213, 2006.

Walker, J. D., Colwell, R. R., Hamming, M. C., Ford, H. T.: Extraction of petroleum hydrocarbons from oil contaminated sediments, Bull. Environ. Contam. Toxicol., 13, 245-248, 1975.

Wang, X., Wang, Q. H., Wang, S. J., Li, F. S., and Guo, G. L.: Effect of biostimulation on community level physiological profiles of microorganisms in field-scale biopiles composed of aged oil sludge, Biores. Technol., 111, 308-315, 2012.

Ward, J. H.: Hierarchical Grouping to Optimize an Objective Function, J. Am. Stat. Assoc., 301, 236-244, 1963. 
Weisskopf, L., Heller, S., and Eberl, L.: Burkholderia Species Are Major Inhabitants of White Lupin Cluster Roots, Appl. Environ. Microbiol., 77, 7715-7720, 2011.

Wilson, L. P., Loetscher, L. H., Sharvelle, S. E., and De Long, S. K.: Microbial community acclimation enhances waste hydrolysis rates under elevated ammonia and salinity conditions, Biores. Technol., 146, 15-22, 2013.

Zakeri, F., Sadeghizadeh, M., Kardan, M. R., Zahiri, H. S., Ahmadian, G., Masoumi, F., Sharafi, H., Rigi, G., Vali, H., and Noghabi, K. A.: Differential proteome analysis of a selected bacterial strain isolated from a high background radiation area in response to radium stress, J. Proteom., 75, 4820-4832, 2012.
Zornoza, R., Guerrero, C., Mataix-Solera, J., Scow, K. M., Arcenegui, V., and Mataix-Beneyto, J.: Changes in soil microbial community structure following the abandonment of agricultural terraces in mountainous areas of Eastern Spain, Appl. Soil Ecol., 42, 315-323, 2009. 